\title{
Post-Processual Archaeology in Sweden 1986-1990
}

\author{
Björn Varenius
}

\begin{abstract}
This paper briefly presents the introduction and early use of postprocessual theories in Sweden, noting that all university departments/ institutes in archaeology to a greater or lesser extent have been influenced by them. The complex and even contradictory character of PPA is emphasized, although not as an epistemological problem.

Björn Varenius, The Central Board of National Antiquities, Box 5405 , S-114 84 Stockholm, Sweden.
\end{abstract}

An article like this, which tries to sum up certain archaeological thinking during a certain timespan, can never be anything but a personal comment. It has not been my intention to make a thorough investigation of all writing that occurred 1986-1990 and that may be considered "post-processual". This article should rather be seen as a few impressions that at best will reflect some of the characteristics of the period in question. Several of the cited works have been important to me in my own research, others have meant less. Some of the authors have perhaps not even thought of their own writing as particularly post-processual.

A discussion of what post-processual archaeology (PPA) stands for can readily become rather confused, since a lot of people have their own idea of what it is. Here, PPA is a collective term for a variety of theories, methods and attitudes, some of which are examined closer below. Postmodernism, post-structuralism, structuralism, semiotics, feminism, Marxism, etc. they all contribute to PPA in one way or another.

\section{ASPECTS OF PPA}

As the name itself implies, post-processual archaeology is a reaction against, or a consequence of, a "processual" archaeology. This is not the place for a lengthy description of the processual "New Archeology" and its various problems, but there is an inevitable logical connection between NA and PPA. This is easily seen in the early PPA literature, which devotes a considerable amount of energy to contradict the main theses of NA: the stress on ecological conditions and the human adaption, the hypothetical-deductive method, the search for "covering laws", the general "explanatory" level, etc.

Instead of $a$ "post-processual archaeology", one should rather speak of "postprocessual archaeologies". Although this may not have been entirely clear from the beginning, PPA covers several theoretical directions. Ian Hodder's contextual archaeology, which he presented more fully in the influential book Reading the Past (1986), had its epistemological roots in the nineteenth-century hermeneutics. This was clearly seen in the references to the British historian R G Collingwood. With this, archaeology definitely entered the field of debate between the "scientific" Erklärung tradition and the Humanistic Verstehen tradition. The contextual reference was, among other things, a plea for the individual and an attempt at 
emphasizing the importance of the totality for the interpretation of the (individual) parts (1986:139). This might be seen as polemical to the earlier, processual systems theory, where identification and analysis of the different "subsystems" were considered an important task.

Semiotics, i.e. the study of signs as a communicative system, including nonverbal communication, is a central part of PPA. Especially Saussure's linguistics has been fundamentally important in its distinguishing between langue, the structural grammar, and parole, the specific message, and between signifiant, the sign, and signifié, the signified (Saussure 1960). It has turned out to be of great relevance as demonstrated by Christopher Tilley in both theory (1990) and practice (1991). Material culture has a communicative function, where the interpretation of its meanings is dependent of a theory of cognitive conventions as an organizer of human thought (and action). Martin Wobst (1977) was an international pioneer in this respect and, as noted below, Jarl Nordbladh had the same role in Sweden. There was an unfortunate lag in the spread of these ideas though, and it was not until the writings of Hodder and Tilley that they were really observed by a large number of scholars. For some reason, archaeologists involved in rock-carvings and petroglyphic art have been particularly interested in semiotics, although there are no such "built-in" limitations in the methodology (cf. Jensen 1989, Llamazares 1989).

The analytical principles of structuralism, especially in Levi-Strauss' version, have great potential in archaeological semiotics, too. This was recently demonstrated by Tilley in his interpretation of the Nämforsen carvings (1991). The human need of classification, i.e. that "reality" does not make sense and is unattainable to the mind until it is classified, is fundamental in structuralism. The concepts are supposedly possible to group and analyse in binary oppositions. Levi-Strauss' works are essential, not least as a source of inspiration and as a general "terminological tool-box". The line of demarcation between semiotics and structuralism is not always self-evident, but to put it (too?) simple, one might say that the former denotes a general theory of signsystems and the latter an operational aspect.

One might have expected that the postmodern thesis, where the meaning in a text (or in a work of art) is seen as being decentred from the author/creator to the reader/ observer, would have had great impact on archaeological research, but this has not been the case, at least not in Sweden 19861990. This is sad, because archaeology ought to be an ideal field for post-structuralism, a whole professional corps occupied with constructing patterns of material culture remains and no "author" there to oppose the results. The major cause of this absence of applications is almost certainly to be found in a fear of relativism, i.e. a relic of positivism, but there is also a conflict within PPA. The demand for "einfühlung" in Hodder's contextual approach is not easily conjoined with the post-modern striving for deconstruction. There is no natural compromise in this contradiction, but that is not necessary or even desirable.

Critical archaeology is something else that may not be thought of as exclusively "post-processual", but which is easily joined with it. From this perspective, it is of great weight to scrutinize how cultural history functions, or rather is used, in our own time and what kind of research that is asked for and rewarded. What are the conditions of research, how are the tasks and the prerequisites described and motivated and how are they apprehended and fulfilled? Feminist archaeology, or perhaps the gender perspective, may be an example of this critical attitude. This could be beneficial on at least two levels: data-growth regarding the strategies and conditions of both men and women, and, secondly, deconstruction of 
monolithic societal definitions (Göransson 1987:46). More than anything else, critical archaeology is a matter of attitude and an $a$ priori questioning of motives and explanations. It is possible that this might serve as a characteristic of the entire PPA.

\section{AN ANGLE OF SWEDISH POST- PROCESSUAL ARCHAEOLOGY 1986- 1990}

There is no doubt that Swedish PPA initially borrowed a great deal of both theory and conceptual terminology from England. Not very surprisingly, most of it came from Cambridge and its archaeological seminar, notably I. Hodder, C. Tilley, M. Shanks, D. Miller, T. Yates and others. Not only British archaeology but other disciplines as well, e.g. sociology and anthropology, have been influential on Swedish archaeologists via the Cambridge seminar. It must be noted, though, that there was one seminar in Sweden where PPA ideas - although the term was not used at that time - were contemporaneous with or even preceded the British, namely the Gothenburg department. Jarl Nordbladh's doctoral thesis from 1980 was a study of the rock-carvings of Bohuslän from an explicit semiotic perspective (see also Nordbladh 1978).

Thomas B. Larsson's dissertation (1986) at the University of Umea was an important step towards an integration of PPA, and perhaps of social theory as such, into Swedish archaeology. His study, titled Bronze Age Metalwork in Southern Sweden, mediates between the former processual concept and the "new" PPA ideas. Methodologically, Larsson relies heavily on numeric, multivariate analyses, but theoretically, he approaches his material from a Marxist standpoint. His prime empirical base is constituted by artefacts, approximately 5000 bronzes, already published by other scholars (Oldeberg 1974-76 and Baudou 1960). Larsson does not question the traditional chronological or taxonomical categories, but focus- es on the different spatial artefact patterns. He interprets these in terms of regional variations of increasing and institutionalized stratification of social organization.

The Department of Archaeology at Stockholm University has been an active forum for PPA ideas since approximately 1986-87. The first more visible result of this was issued in 1988, Samhällsteori och källmaterial - aktuell arkeologi II (ed. Åke Hyenstrand). Eight post-graduate students presented their work and at least three of them displayed an interest in PPA. A thorough survey of the "stand der forschung" of PPA up to 1987 was carried out by Ronnie Jensen, while Mats Burström and Mikael Jakobsson published papers dealing with regional identity and power structures in Iron Age societies. Jensen, Burström and Jakobsson also contributed to a volume in 1989, Mänsklighet genom Millennier, as did Leif Gren and Inger Hedengran. Gren discussed the erection of medieval stone churches as a mounumental, symbolical manifestation of the early Christian hierarchical world view. This perspective on the church parish and its establishment in the twelfth century was largely constructed from the history of thought, an exciting aspect.

Hedengran tried a structural-analogy model for the identification and evaluation of invested labour/care in two different prehistoric grave contexts, but had considerably developed her thoughts in PPA direction by 1990 , when she presented a paper in Fornvännen (1990:219-238), titled Skeppet $i$ kretsen (The Ship in the Circle). Here she analyses the structural relationship between several kinds of ancient monuments, e.g. a rock-carving scene from Boglösa parish, Uppland - which includes a triple circle, a ship that partly crosses the circles, a footsole and a man - and a cairn from Östertälje parish, Södermanland. The cairn exhibited a number of features, including a stone construction resembling a ship's prow that seemed to penetrate the line 
of kerbstones. The burned bones of an elderly woman were found together with a few bronze fragments. The different materials are assumed to express a basic symbolical structure, "the travel and the space", ideas of rites de passages that were rooted in a cyclical apprehension of time and life.

The same issue of Fornvännen contained two more articles on the PPA theme. In one of these, Elisabeth Arwill-Nordbladh (at the Gothenburg department) looks into the problem of the keys that are sometimes found in Vendel- and Viking Age female graves. It is argued that a single key may not symbolize the economic control over the farm, as is sometimes claimed, but rather represents the woman's individual integrity, a non-accessible domain. Arwill-Nordbladh sees the keys as open to a number of different symbolic interpretations, according to context-specific situations.

In the other paper, Mats Burström questions the credibility of the pervailing economical and functional approach to the occurrance of iron slag in Viking Age graves in Gästrikland and argues that it should be symbolically understood (1990). He takes a standpoint in the structural transformation the furnace slag undergoes as it is let out of its producer, the furnace. The slag's transformation from a hot, bright, sizzling and movable "outcome" to something cold, dark, silent and stiff can be seen as a structural parallel to what happens when a human individual dies. In both cases the change of state is connected with fire. These resemblances can make the deposition of slag in graves culturally meaningful and not primarily the reflexion of economical necessities.

The same author has at some length discussed the question of archaeological perspectives (1989b). The pluralism of meaning of the material culture is seen as fundamental to the understanding of the past. Burström showed that different "pasts" will be perceived from different angles, i.e. archaeological perspectives. The discussion of the consequences of this thesis - together with a somewhat provocative language obviously stirred up feelings. There were demands that the book must be withdrawn. Retrospectively, this does seem hard to believe, since today it has been accepted as obligatory literature in a number of university courses.

In a discussion of the nature of spiritual beliefs, Bo Gräslund at the Uppsala department presented the idea of a pluralistic spiritual concept, implicating a "body-soul" that leaves the body at (physical) death and a "free-soul" that has to be liberated by the mortuary ritual (Gräslund 1989). This ethno-archaeologically motivated dualism of the soul is relevant to the interpretation of archaeological material, not least the grave-goods, actually from the Neolithic to the end of the Viking Age. Gräslund points to the fact that the grave-goods are always treated in the same way as the human body, following the change of ritual to cremation during the Bronze Age.

In Lund, PPA-related research was conducted already in the early 1980 s, notably in Kristina Jennbert's research regarding the neolithization as an effect of social strategies (and not of evolution) (Jennbert 1984). The same author has also devoted considerable energy to the problematization of the grave - a "language" which she sees as an expression of the general mentality of society (Jennbert 1988:87). The seminar for medieval archaeology rather quickly picked up the PPA discussion, preferably visible in the periodical META, issued four times a year. One proof of this is nr 1-2 1988, which deals with the very foundation of "medieval archaeology". Anders Andrén and Jes Wienberg investigate thoroughly and at some length the empirical and theoretical prerequisites and characteristics of the relationship between "things and texts". Erik Cinthio and Hans Andersson do more of learned exposés over the rise and raison d'être of the insti- 
tutional subject they have been chosen to govern and Eva Österberg makes certain trend comparisons with her own subject, history. In nr 2 1989, Stig Welinder confronted the idea of specialized institutes for medieval/historical archaeology, but also saw arguments for several more institutes with this competence. What is important is the plea for a contextual, human approach to medieval man, and the rejection of the view that considers the study of the Middle Ages a question of data-collecting, labelling and other pseudo-scientism.

Another debate that came up in the same periodical concerned chaos (1989/3 and 1989/4). Wienberg initiated it with an article titled Kaos $i$ tiden (Chaos in time). He referred to chaos-research as the natural science's re-establishment of interest in "little unique events" (1989a:68), and paralleled this with archaeology's contextualism. Both would disapprove of general explanatory laws and deal with alternate scenarios, dependent on individual acts or events. For Wienberg, this indicated that they both belong to the same contem-porary, hermeneutic tendency.

For a while, one would have thought that this would open up a new field in Swedish archaeology, but that did not happen. Again, Welinder contributed and again, he was sharp and critical. He refuted Wienberg's opinion that chaos-research was about the physicist's acknowledgment of the little and chaotic forces of existence and argued that it was more of a computerbased systematizing of hitherto unreachable aspects of the physical reality (1989:5152). His comparisons were far more pessimistic and he saw chaos-research as yet another attempt by man, and especially by medical science, to control nature, like in genetic manipulation and organ transplantation. The debate faded away in some disputation between Wienberg/Welinder and the editor(s) concerning whether or not the Humanities also this time were dependent upon the natural sciences for inspiration and theory-building (1990).

\section{CONCLUDING REMARKS}

In this paper, I have tried to summarize some impressions from a debate that now seems rather distant, and also to give a hint of what post-processual archaeology is (was?) about. The wisdom in attempting these endeavours can be seriously questioned, especially the latter. Perhaps it is easier to say what PPA is not than what it is. It is not an attempt to replace "good old" empirical knowledge of the past with "lofty" relativistic speculations. It is not a way of expressing the self-evident with complicated words. On the contrary, it is more of putting the complicated into relevant words. It is not willing to replace the notion of practical function with that of symbolical meaning, but it advocates that both aspects must be included in an interpretation. Since a lot of both "traditional" and "new" archaeology has been occupied with isolated function, the insistance of PPA that symbolism is a part of social function has been misunderstood as a sole interest in the sphere of symbols.

If anything, PPA has tried to show that the empiricism is just as theory-laden as any "shanksandtilleyism". The final criterion of a functioning PPA is of course whether an archaeological material can be interpreted in a thought-provoking and convincing way or not. With yet another paraphrase of Willey and Phillips (1958) it could be stated that "(post-processual) archaeology is application or it is nothing". This, however, cannot be separated from an interest in how archaeological knowledge and knowledge as such - comes into being, what constitutes that which is considered worth knowing and how knowledge is communicated. This is not unique for PPA, but it is an important part of it.

English revised by Laura Wrang. 


\section{REFERENCES}

Andersson, H. 1988. Medeltidsarkeologi - funderingar kring identitet och förhållningssätt, META 1988:1-2. Lund.

Andrén, A. 1988. Ting och text - skisser till en historisk arkelogi. META 1988:1-2. Lund.

Arwill-Nordbladh, E. 1990. Nyckelsymbolik i järnålderns kvinnogravar. Fornvännen. Stockholm.

Baudou, E. 1960. Die regionale und chronologische Einteilung der jüngeren Bronzezeit im Nordischen Kreis. Studies in North European Archaeology 1. Stockholm.

Burström, M. 1988. Regional identitet och territoriell organisation. Exemplet inre Sydsverige under järnålder. In: Samhällsteori och källmaterial - aktuell arkeologi II (ed. $\AA$ Hyenstrand). Stockholm Archaeological Reports 21. Stockholm.

- 1989a. Kronologi och kontext. Om samtidighetens relevans för den arkeologiska tolkningen. In: Mänsklighet genom millennier. En vänbok till Åke Hyenstrand. Stockholm.

- 1989b. Arkeologiskt perspektivmedvetande. Stockholm Archaeological Reports 23. Stockholm.

- 1990. Järnframställning och gravritual. En strukturalistisk tolkning av järnslagg i vikingatida gravar i Gästrikland. Fornvännen. Stockholm.

Cinthio, E. 1988. Examensämnet Medeltidsarkeologi. META 1988:1-2. Lund.

Gren, L. 1989. Platon mitt i byn. Kyrksocknens uppkomst från monumentologisk synpunkt. In: Mänsklighet genom millennier. En vänbok till Åke Hyenstrand. Stockholm.

Gräslund, B. 1989. Forntida själstro i arkeologisk belysning. Kungl. Vitterhets och Antikvitets Akademiens årsbok 1989. Stockholm.

Göransson, A. 1987. Innovation och institution. Om receptionen av kvinnohistoria och kön som analytisk kategori. In: Manliga strukturer och kvinnliga strategier. En bok till Gunhild Kyle (eds. B Sawyer and A Göransson). Göteborg.

Hedengran, I. 1989. Omsorg vid Dragby och omsorg vid Fiskeby. En fråga om skillnad i social struktur och organisation eller $i$ identifikation av omsorg? In: Mänsklighet genom millennier. En vänbok till Åke Hyenstrand. Stockholm.

- 1990. Skeppet i kretsen. Kring en symbolstruktur i Mälardalens förhistoria. Fornvännen. Stockholm.

Hodder, I. 1986. Reading the past. Current approaches to interpretation in archaeology. Cambridge.

Jakobsson, M. 1988. Krigarsamhälle - en modell för yngre järnålder. In: Samhällsteori och källmaterial-aktuell arkeologi II (ed. Å Hyenstrand). Stockholm Archaeological Reports 21. Stockholm.

- 1989. Meningspluralismen i källmaterialet den kontextuella arkeologins dilemma och möjligheter. In: Mänsklighet genom millennier. En vänbok till Åke Hyenstrand. Stockholm.

Jennbert, K. 1984. Den produktiva gåvan. Tradition och innovation $i$ Sydskandinavien för omkring 5300 ar sedan. Acta Archaeologica Lundensia. Series in $4^{0}$. Diss.

- 1988. Gravseder och kulturformer. I arkeologins gränsland. In: Gravskick och gravdata. Rapport från arkeologidagarna 13-15 januari 1988. (Eds. E. Iregren, K. Jennbert, L. Larsson). University of Lund, Institute of Archaeology. Report series No 32. Lund.

Jensen, R. 1988. Anteckningar om postprocessuell arkeologi. In: Samhällsteori och källmaterial-aktuell arkeologi II (Ed. Å. Hyenstrand). Stockholm Archaeological Reports 21. Stockholm.

- 1989. Materiell kultur som kommunikativ förmedlare - några semiotiska begrepp med arkeologiska exempel. In: Mänsklighet genom millennier. En vänbok till Åke Hyenstrand. Stockholm.

Larsson, T.B. 1986. The Bronze Age Metalwork of Southern Sweden. Aspects of Social and Spatial Organization 1800-500 BC. Archaeology and Environment 6. University of Umeå. Diss. Llamazares, A.M. 1989. A semiotic approach in rock-art analysis. In: The Meaning of Things. Material Culture and Symbolic Expression (ed. I. Hodder). One World Archaeology. London. META - Medeltidsarkeologisk tidskrift. Issued by: Medeltidsarkeologiska föreningen, The Histo- 
rical Museum of the University of Lund, Krafts torg 1, S-223 50 Lund.

Nordbladh, J. 1978. Images as Messages in Society. Prolegomen to the Study of Scandinavian Petroglyphs and Semiotics. In: New Directions in Scandinavian Archaeology (Eds. K. Kristiansen \& C. Paludan-Müller. Köpenhamn.

-1980. Glyfer och rum. Kring hällristningar $i$ Kville. Diss. Göteborg.

Oldeberg, A. 1974-76. Die ältere metallzeit in Schweden I-II. Kungl. Vitterhets Historie och Antikvitets Akademien. Stockholm.

Saussure, F. de 1960. Course in general linguistics. Peter Owen. London.

Tilley, C. 1990. Claude Levi-Strauss: Structuralism and beyond. In: Reading Material Culture (ed. C. Tilley). Oxford.

- 1991. Material Culture and Text. The Art of Ambiguity. London.

Welinder, S. 1989. Kaos i huvet på... . META
1989:4. Lund.

Welinder, S. \& Wienberg, J. 1990. Kaos i debatten. META 1990:1-2. Lund.

Wienberg, J. 1988. Metaforisk arkæologi og tingenes sprog. META 1988:2. Lund.

- 1989a. Kaos i tiden. META 1989:3. Lund.

- 1989b. Kaos i kaosforskningen. META 1989:4. Lund.

Willey, G. \& Phillips, P. 1958. Method and theory in American archaeology. University of Chicago Press.

Wobst, M. 1977. Stylistic Behaviour and Information Exchange. In: For the Director. Research Essays in Honour of James $B$ Griffin. Anthropological Papers No 61, Museum of Anthropology, University of Michigan. Ann Arbor. Michigan.

Österberg, E. 1988. Trender i historisk forskning om äldre tid och kontaktytor mellan medeltidsarkeologi och historia. META 1988:2. Lund. 
